\title{
Poema inédito
}

Ernesto Manuel de Melo e Castro

Poeta

ercastropt@gmail.com

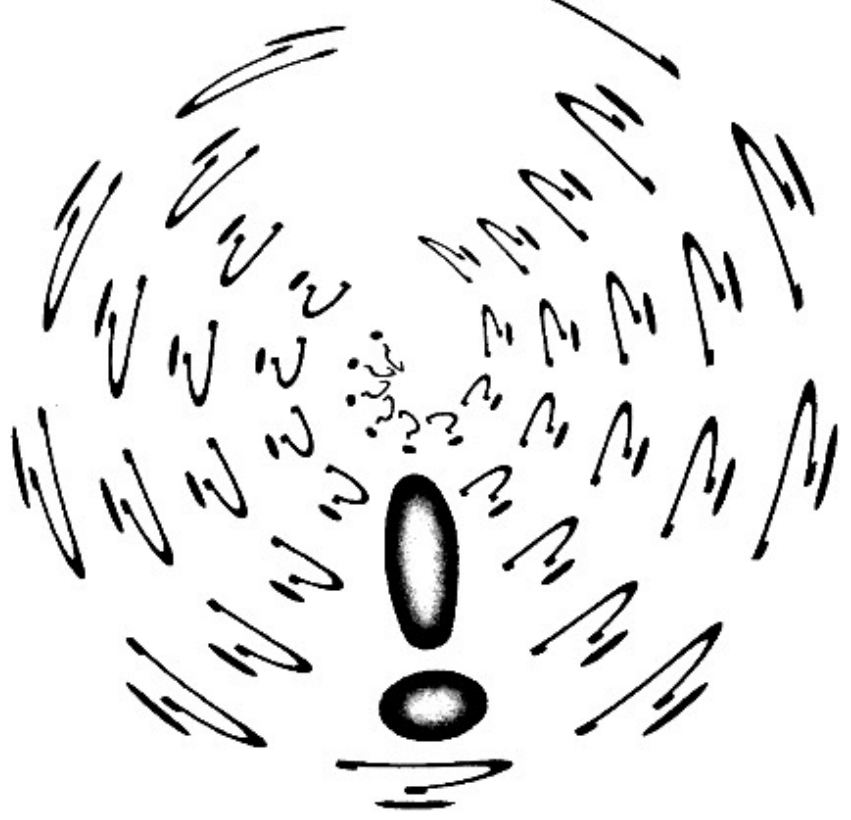

Recebido em: 28 de outubro de 2019.

Aprovado em: 15 de dezembro de 2019. 